\title{
Hypoxia/Reoxygenation Impairs Memory Formation via Adenosine-Dependent Activation of Caspase 1
}

\author{
Gabriel S. Chiu, ${ }^{1,2}$ Diptaman Chatterjee, ${ }^{2}$ Patrick T. Darmody, ${ }^{2}$ John P. Walsh, ${ }^{2}$ Daryl D. Meling, ${ }^{2}$ Rodney W. Johnson, ${ }^{3}$ \\ and Gregory G. Freund ${ }^{1,2,3}$ \\ ${ }^{1}$ Division of Nutritional Sciences, ${ }^{2}$ Department of Pathology, Program in Integrative Immunology and Behavior, and ${ }^{3}$ Department of Animal Sciences, \\ University of Illinois, Urbana Illinois 61801
}

\begin{abstract}
After hypoxia, a critical adverse outcome is the inability to create new memories. How anterograde amnesia develops or resolves remains elusive, but a link to brain-based IL-1 is suggested due to the vital role of IL-1 in both learning and brain injury. We examined memory formation in mice exposed to acute hypoxia. After reoxygenation, memory recall recovered faster than memory formation, impacting novel object recognition and cued fear conditioning but not spatially cued Y-maze performance. The ability of mice to form new memories after hypoxia/reoxygenation was accelerated in IL-1 receptor 1 knockout (IL-1R1 KO) mice, in mice receiving IL-1 receptor antagonist (IL-1RA), and in mice given the caspase 1 inhibitor Ac-YVAD-CMK. Mechanistically, hypoxia/reoxygenation more than doubled caspase 1 activity in the brain, which was localized to the amygdala compared to the hippocampus. This reoxygenation-dependent activation of caspase 1 was prevented by broad-spectrum adenosine receptor (AR) antagonism with caffeine and by targeted A1/A2A AR antagonism with 8-cyclopentyl-1,3-dipropylxanthine plus 3,7-dimethyl-1-propargylxanthine. Additionally, perfusion of adenosine activated caspase 1 in the brain, while caffeine blocked this action by adenosine. Finally, resolution of anterograde amnesia was improved by both caffeine and by targeted A1/A2A AR antagonism. These findings indicate that amygdala-based anterograde amnesia after hypoxia/ reoxygenation is sustained by IL- $1 \beta$ generated through adenosine-dependent activation of caspase 1 after reoxygenation.
\end{abstract}

\section{Introduction}

Injury to the brain through loss of oxygen triggers memory loss and causes learning deficiencies (Shukitt-Hale et al., 1996), including anterograde amnesia (Beatty et al., 1987). Importantly, acute hypoxia activates the neuroimmune system, especially its IL-1 arm (Johnson et al., 2007). Brain-based IL-1 regulates cognitive function (Dantzer et al., 2008), and excess IL-1 in the brain is congruous with memory loss and impaired learning (Pugh et al., 2001). While neuroimmune system-generated IL-1 can cause brain injury (Ma et al., 2003), the mechanism by which IL-1 is produced in the brain during reduced oxygen conditions is not understood. IL- $1 \alpha$ and IL- $1 \beta$ are both present in the brain, and each is implicated in complications related to hypoxia and ischemia (Touzani et al., 1999). Previously, we demonstrated that delayed recovery from acute hypoxia, as measured by social withdrawal in mice, was reliant on IL- $1 \beta$ because inhibition of the inflammatory caspase, caspase 1 , dramatically shortened recuperation time (Johnson et al., 2007). As a member of the cysteine-

Received Feb. 14, 2012; revised July 31, 2012; accepted Aug. 9, 2012.

Author contributions: G.S.C., R.W.J., and G.G.F. designed research; G.S.C., D.C., P.T.D., J.P.W., and D.D.M. performed research; G.C. and G.G.F. analyzed data; G.C. and G.G.F. wrote the paper.

This research was supported by the National Institutes of Health Grants DK064862, NS058525, and AA019357 (to G.G.F.) and a Ruth L. Kirchstein National Research Service Award (DK59802) to the Division of Nutritional Sciences (predoctoral fellowship to G.S.C.).

Correspondence should be addressed to Dr. Gregory G. Freund, Department of Pathology, College of Medicine, 506 South Mathews Avenue, University of Illinois at Urbana-Champaign, Urbana, IL 61801. E-mail: freun@illinois.edu.

DOI:10.1523/JNEUROSCI.0704-12.2012

Copyright $\odot 2012$ the authors $\quad 0270-6474 / 12 / 3213945-11 \$ 15.00 / 0$ aspartic acid protease family, caspase 1 exists intracellularly as an inactive proenzyme (Damiano et al., 2004) until it is proteolytically processed by Nod-like receptor (NLR)-containing multiprotein inflammasomes (Miao et al., 2011). Activated caspase 1 enzymatically processes pro-IL- $1 \beta$ to a secretable mature form (Bauernfeind et al., 2009). Inflammasome activation is elicited by a variety of microbe- and host-associated bioactives (Schroder et al., 2010), including endogenous danger signals generated during reoxygenation such as reactive oxygen species (ROS) (Tschopp et al., 2010), uric acid (Lamkanfi et al., 2007), and ATP (Di Virgilio, 2007).

The restoration of oxygen after hypoxia is required for recovery but can, itself, cause tissue damage (González-Correa et al., 2007). Reoxygenation is frequently described in conjunction with reperfusion as occurs in ischemic injuries like myocardial infarction (Galaris et al., 1989) and stroke (Kostulas et al., 1999). Recently, reoxygenation unassociated with reperfusion has been linked to neural injury and cognitive dysfunction associated with sleep apnea (Gozal et al., 2001). Hypoxia/reoxygenation can precipitate endoplasmic reticulum stress (Bi et al., 2005), cell death (Saikumar et al., 1998), and inflammation (Johnson et al., 2007), but the means by which hypoxia/reoxygenation triggers these sequelae is not clear. Currently, hypoxia/reoxygenationdependent generation of ROS is a favored causative to reoxygenation injury (Li and Jackson, 2002), but membrane destabilization is also a consequence of hypoxia/reoxygenation (Bickler and Hansen, 1994; Calabresi et al., 1995). Importantly, membrane damage causes increases in extracellular concentrations of ATP, ADP, and adenosine (Guinzberg et al., 2006). 
Intracellular adenosine concentrations rapidly increase during states of negative energy balance when ATP hydrolysis outstrips ATP synthesis (Bruns, 1991; Fredholm et al., 1999). In contrast, extracellular adenosine is primarily derived from enzymatic phosphohydrolysis of ATP in the interstitial space (Hart et al., 2008). During hypoxia and ischemia, the extracellular concentration of adenosine can increase from 30-300 nм (Rudolphi and Schubert, 1997) to $10-50 \mu \mathrm{M}$ (Hagberg et al., 1987). In addition, extracellular AMP derived from intracellular ATP and ADP can be phosphohydrolyzed by CD73 to adenosine (Kobie et al., 2006). G protein-coupled adenosine receptors (ARs), which are divided into the subclasses $\mathrm{A} 1, \mathrm{~A} 2 \mathrm{~A}, \mathrm{~A} 2 \mathrm{~B}$, and $\mathrm{A} 3$, all recognize extracellular adenosine (Fredholm et al., 2001) and are blocked by the nonselective lipophilic competitive antagonist and nutraceutical, caffeine (Fredholm et al., 1999), as well as specific pharmacologic inhibitors. Therefore, in this study we sought to show that memory formation after acute hypoxia is adversely impacted by brain IL- $1 \beta$ through a mechanism reliant on AR-dependent activation of caspase 1 .

\section{Materials and Methods}

Materials. All reagents and chemicals were purchased from SigmaAldrich except as noted. All primers were purchased from Applied Biosystems.

Animals. Animal use was conducted in accordance with Institutional Animal Care and Use Committee-approved protocols at the University of Illinois (Urbana, IL). C57BL/6J male animals were purchased from The Jackson Laboratory at 7 weeks of age. C57BL/6J IL-1 receptor 1 knock-out (IL-1R1 KO) mice were bred in-house. Mice were group housed ( $\times 8$ cage) in standard shoebox cages (length, $46.9 \mathrm{~cm}$; width, 25.4 $\mathrm{cm}$; height, $12.5 \mathrm{~cm}$ ) and allowed water and food ad libitum. Housing temperature $\left(72^{\circ} \mathrm{F}\right)$ and humidity $(45-55 \%)$ were controlled as was a $12 / 12 \mathrm{~h}$ reversed dark-light cycle (2200-1000 h). Video recording of animal behavior was performed under red light using a night shotcapable video camera (Sony HDR-XR500V). Except for locomotor activity, which was performed as a repeated measure, all treatments at all time points represent separate cohorts of mice. The total number of mice used was 630 .

Intracerebroventricular cannulation. As we have described previously (Johnson et al., 2007), mice were anesthetized intraperitoneally with a sodium ketamine hydrochloride/xylazine hydrochloride solution delivering 80 $\mathrm{mg} / \mathrm{kg}$ ketamine and $12 \mathrm{mg} / \mathrm{kg}$ xylazine. Animals were placed in a Kopf stereotaxic instrument (David Kopf Instruments), and mouse-specific brain infusion cannulas (Plastics One) were placed using the coordinates $0.6 \mathrm{~mm}$ posterior, $1.5 \mathrm{~mm}$ lateral to the bregma, and $2.5 \mathrm{~mm}$ ventral from the surface of the skull. Cannulas were fixed to the skull with cyanoacrylate gel adhesive (Plastics One) and protected by a plastic guard. Mice were allowed 7 days to recover.

Hypoxia/reoxygenation. As we have described previously (Sherry et al., 2009a,b), mice ( $n=16 /$ episode) were transferred from their home cages to the BioSperix ProOx/A-Chamber Biological Atmosphere System (Biospherix) and subjected to either a 6\% oxygen and 94\% nitrogen environment (hypoxia) or an atmospheric air environment (normoxia) for $2 \mathrm{~h}$. After exposure, mice were returned to their home cages.

Injectables. As we have described previously (Johnson et al., 2007), the caspase 1 inhibitor Ac-YVAD-CMK (Bachem) was administered intracerebroventricularly at a dose of $50 \mathrm{ng} / \mu \mathrm{l} /$ mouse immediately before hypoxia. Kineret, a recombinant IL-1 receptor antagonist (IL-1RA) (AmGen), was administered intraperitoneally at a dose of $1.4 \mathrm{mg} / \mathrm{kg} / \mathrm{mouse} 30 \mathrm{~min}$ before hypoxia. CafCit (caffeine citrate) (Bedford Laboratories) was administered intraperitoneally at a dose of $100 \mathrm{mg} / \mathrm{kg} /$ mouse immediately before hypoxia. 8-cyclopentyl-1,3-dipropylxanthine [A1 AR antagonist (2.5 mg/kg/mouse)] plus 3,7-dimethyl-1-propargylxanthine [A2A AR antagonist $(2.5 \mathrm{mg} / \mathrm{kg} /$ mouse)] (Chen et al., 2001) were administered as an intraperitoneal cocktail $1 \mathrm{~h}$ before hypoxia. $\mathrm{N}$-acetyl cysteine (NAC) (Hospira) was administered intraperitoneally at a dose of $50 \mathrm{mg} / \mathrm{kg} /$ mouse immediately before hypoxia. For all studies, vehicle/control injection was phosphate-buffered saline
(PBS) or normal saline (saline), as indicated, except for targeted AR inhibition, which was 1:5 DMSO/castor oil.

Novel object recognition. Novel object recognition was performed as we have described previously (Lavin et al., 2011; York et al., 2012b). In studies examining retrograde amnesia, mice ( $1 \mathrm{~h}$ before hypoxia) were individually transferred from their home cage to a home cage-sized memory arena containing two identical objects placed $10 \mathrm{~cm}$ apart at the short-side wall end for $5 \mathrm{~min}$ (training). Mice were then subjected to hypoxia or normoxia. At the time points indicated post-hypoxia, mice (individually) were transferred back to the memory arena now containing one familiar object and one unfamiliar object (novel object) (testing). Investigative behavior of the objects was video recorded for $5 \mathrm{~min}$ and evaluated using EthoVision XT 7 (Noldus Information Technology) video tracking software. Percent investigation was calculated by dividing the time spent examining each object by the total time spent investigating both objects. In studies examining anterograde amnesia, mice were transferred for training at the time points indicated post-hypoxia. Mice were then returned to their home cage for $55 \mathrm{~min}$. As above, testing was initiated by returning mice to the memory arena with one familiar object and one novel object. Investigative behavior of the objects and time spent examining each object were performed as described above.

Locomotion. Spontaneous locomotor activity was measured as we have described previously (Lavin et al., 2011, York et al., 2012a). At the times indicated, mice were video recorded in their home cage for $5 \mathrm{~min}$. Distance moved was quantified using EthoVision XT 7.

Cued fear conditioning. Cued fear conditioning was performed as we have described previously (York et al., 2012b). Four hours post-hypoxia, mice were placed in a Lafayette Instruments Cued and Contextual Fear Test Chamber. After a $30 \mathrm{~s}$ acclimatization period, mice were exposed to a white light $(\sim 23000$ lux $)$ for $2 \mathrm{~s}$, followed by a $2 \mathrm{~s}$ foot shock $(60 \mathrm{~V}, 1$ $\mathrm{mA}$ ). After a $30 \mathrm{~s}$ wait, mice were re-exposed to the light plus foot shock cycle as described above (training). Mice were then returned to their home cage. At the time points indicated, mice were reintroduced to the testing apparatus and allowed to acclimate for $30 \mathrm{~s}$. Mice then underwent two cycles of light without foot shock similar in parameters to the above (testing). All freezing behavior was evaluated via an integrated infrared photo beam array. Data were analyzed using the Motor Monitor Host Software (Lafayette Instruments).

Alternation. Spatially cued spontaneous alternations were performed as we have described previously (Lavin et al., 2011, York et al., 2012b). In brief, mice were placed in a symmetrical three-arm, clear Plexiglas Y-maze $(40 \mathrm{~cm}$ length $\times 9 \mathrm{~cm}$ width $\times 16 \mathrm{~cm}$ height per arm with an arm angle of $120^{\circ}$ ) with side walls decorated with black triangles, black circles, or black diagonal lines. Mice were randomly placed in one of the arms. Movement was recorded for $5 \mathrm{~min}$ and mouse exploration was evaluated from the video record. Mice were tested at 4, 52, and $76 \mathrm{~h}$ after hypoxia. Results are presented as the ratio of perfect alternations to total arm entrances. Perfect alternations were defined as exploration of two novel arms sequentially before a return to the start arm independent of a right or left arm choice at initiation. To have entered an arm, the mouse was required to have all four legs in that arm.

Quantitative PCR. As we have described previously (York et al., 2012a), RNA was isolated from the hippocampus dissected from PBS-perfused whole brains. RNA was reverse transcribed using the High-Capacity cDNA Reverse Transcription Kit (PN 4368813; Applied Biosystems). The TaqMan Gene Expression primers used were glial fibrillary acidic protein (GFAP) (Mm01253033_m1), aquaporin 4 (Mm000802131_m1), CD11b (Mm00434455_m1), F4/80 (Mm00802529_m1), and the peripheral benzodiazepine receptor (PBR) (Mm00437828_ml). Quantitative PCR (qPCR) was performed on a 7900 HT Fast Real-Time PCR System (Applied Biosystems) using TaqMan Universal PCR Master Mix (Applied Biosystems). To compare gene expression, a parallel amplification of endogenous RPS3 (Mm00656272_m1) was performed. Reactions with no reverse transcription and no template were included as negative controls. Relative quantitative evaluation of target gene to RPS3 was performed by comparing $\Delta \mathrm{Cts}$, where $\mathrm{Ct}$ is the threshold concentration.

Caspase 1 activity. PBS-perfused whole brains, brain regions (as indicated), and livers were frozen in liquid nitrogen and then freeze fractured in reaction buffer containing $50 \mathrm{~mm} \mathrm{NaCl}$ (Fisher Scientific), 

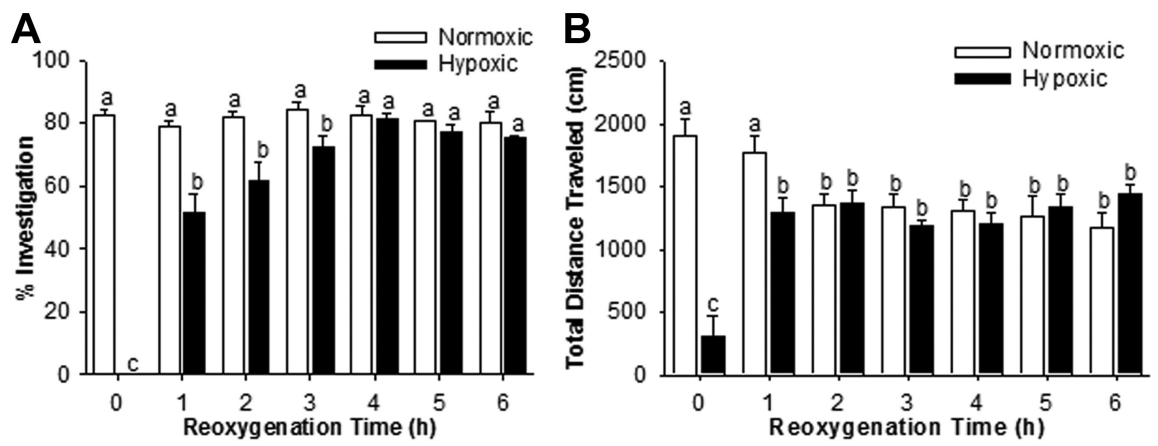

Figure 1. Restoration of memory recall after acute hypoxia. $\boldsymbol{A}$, Wild-type mice were trained in memory formation using novel object recognition $1 \mathrm{~h}$ before hypoxia. Mice were then exposed to normoxia or hypoxia for $2 \mathrm{~h}$. Memory recall (percent investigation) was measured at the reoxygenation time points indicated. Results are expressed as means $\pm S E M ; n=8$. Bars without a common superscript are different $(p<0.05$ ). $\boldsymbol{B}$, Mice were treated as in $\boldsymbol{A}$, and spontaneous locomotor activity (total distance traveled) was measured at the reoxygenation time points indicated. Results are expressed as means $\pm \mathrm{SEM} ; n=6$. Bars without a common superscript are different $(p<0.05)$.

10\% glycerol, $1 \mathrm{~mm}$ DTT, $1 \mathrm{~mm}$ EDTA, $1 \mathrm{~mm}$ bestatin, $1 \mathrm{~mm}$ pepstatin (EMD4Bioscience), 1 mM 4-(2-aminoethyl)benzenesulfonyl fluoride hydrochloride, and $50 \mathrm{~mm}$ HEPES, pH 7.4 (USB Corporation) using the TissueLyser II (Qiagen) at a rotational frequency of 30/s for $2 \mathrm{~min}$. Lysates were clarified at $16,000 \times g$ for $15 \mathrm{~min}$ at $4^{\circ} \mathrm{C}$, and the supernatant protein concentrations were determined using the DC Protein Assay (Bio-Rad) and a ELx800 Absorbance Microplate Reader (BioTek Instrument). Supernatant protein concentrations were normalized to 10 $\mathrm{mg} / \mathrm{ml}$ (whole brain and liver) or $2.5 \mathrm{mg} / \mathrm{ml}$ (brain regions) with reaction buffer. Caspase 1 activity was determined colorimetrically in the clarified lysates using the caspase 1 substrate Ac-YVAD-p-nitroaniline (p-NA) (Enzo Life Science) at a final concentration of $4 \mathrm{~mm}$. Substrate incubation was at $37^{\circ} \mathrm{C}$ for the times indicated. Moles of p-NA liberated were determined by a standard curve ranging from $0.075 \mathrm{~mm}$ to $0.3 \mathrm{~mm}$-NA (Enzo Life Science). Caspase 1 activity was calculated as $(\Delta[\mathrm{p}-\mathrm{NA}] / \Delta$ time $) /$ (total protein).

Adenosine perfusion. Mice were killed via $\mathrm{CO}_{2}$ asphyxiation, and the heart was immediately exposed using straight $11.5 \mathrm{~cm}$ scissors (Fine Science Tools). The left ventricle was pieced with a 23 gauge, 1.25 inch needle (BD) attached to a $\mathrm{BD} 30 \mathrm{ml}$ syringe. Mice were perfused (as indicated) with $10,30,50$, or $100 \mu \mathrm{M}$ adenosine, $500 \mu \mathrm{M}$ NAC, $500 \mu \mathrm{M}$ caffeine, $50 \mu \mathrm{M}$ adenosine plus $500 \mu \mathrm{M}$ caffeine, or $50 \mu \mathrm{M}$ adenosine plus $500 \mu \mathrm{M}$ NAC in PBS, pH 7.4, or PBS alone, pH 7.4.

Glutathione. Similar to methods we have described previously (Godbout et al., 2002), glutathione (GSH) and glutathione disulfide (GSSG) were measured using the Glutathione Assay Kit (Sigma-Aldrich). As above, PBS perfused whole brains were frozen in liquid nitrogen and then freeze fractured in the kit-provided assay buffer using TissueLyser II. After brain homogenization, GSH/GSSG was quantified spectrophotometrically following the instructions of the manufacturer and an ELx800 Absorbance Microplate Reader (BioTek Instruments).

Phospho-ERK 1/2, phospho-p38 MAPK, and phospho-JNK. Similar to methods we have described previously (Sherry et al., 2007), whole brains were frozen in liquid nitrogen and then freeze fractured as above in a homogenization buffer containing $50 \mathrm{~mm} \mathrm{NaCl}, 10 \%$ glycerol, $1 \mathrm{~mm}$ DTT, 2 mm sodium orthovanadate, $250 \mathrm{~nm}$ okadaic acid, 1:200 Protease Inhibitor Cocktail III (Calbiochem), and 50 mM HEPES, pH 7.4, using the TissueLyser II (Qiagen). Lysates were clarified at $16,000 \times g$ for 15 $\min$ at $4^{\circ} \mathrm{C}$, and the supernatant protein concentrations were determined using the DC Protein Assay, as above. Phospho (p)-ERK 1/2, p-p38 MAPK, and p-JNK were measured in $50 \mu \mathrm{l}$ of lysate using a Bio-Plex phosphoprotein assay (Bio-Rad) and a Luminex 100 System following the instructions of the manufacturer (Luminex). Results are expressed relative change in phosphorylation/total protein.

Immunohistochemistry. Similar to methods we have described previously (Johnson et al., 2007, Davis-Devine et al., 2003), mice were perfused with ice-cold, 10\% neutral, buffered formalin. Brains were removed and, using a Zivic Mouse Brain Slicer (Zivic Instruments), cor- onal sections ranging from the bregma to -3.0 $\mathrm{mm}$ from the bregma were generated. These slices were fixed in 10\% neutral buffered formalin for $24 \mathrm{~h}$ and then paraffin embedded and sectioned. A $4 \mu \mathrm{m}$ section at $-1.7 \mathrm{~mm}$ from the bregma was immunostained for GFAP using a rabbit anti-GFAP antibody (DAKO) at a dilution of 1:2000 at room temperature for 30 min. Detection was performed using the Rabbit Link/SS Label detection kit (Biogenex) in conjunction with the Biogenex i6000 Automated Staining System (incubation time was $15 \mathrm{~min})$. After coverslipping, the entire slide was imaged at $40 \times$ with a NanoZoomer 2.0-HT (Hamamatsu).

Uric acid. Blood was collected via cardiac puncture using a $26 \mathrm{G} \times 3 / 8$ inch needle (Becton Dickinson) and allowed to stand at room temperature for $30 \mathrm{~min}$. Serum was generated by centrifuging samples at $10,000 \times g$ for 15 min. Serum uric acid was determined on a AU680 analyzer (Beckman Coulter).

Statistics. All data are presented as mean \pm SEM. Data were analyzed using SigmaPlot 11.2 (Systat Software). To test for statistical differences, a one-way or two-way ANOVA was used with or without repeated measurements where needed. Tukey's test was used for post hoc, pair-wise, multiple-comparison procedures. Where indicated, raw data were transformed using a $\log 10$ transformation to attain equal variance. All statistical analysis included testing for time point $\times$ treatment interactions. Statistical significance was denoted at $p<0.05$.

\section{Results}

\section{Restoration of memory recall after acute hypoxia}

Figure $1 A$ demonstrates that if memory formation (training) occurred $1 \mathrm{~h}$ before hypoxia, the ability of mice to recall that memory in the testing phase was restored after $4 \mathrm{~h}$ of reoxygenation $(82.5 \pm 2.1 \%$ vs $81.3 \pm 2.1 \%$, normoxia vs hypoxia). Immediately after hypoxia, mice did not explore either a familiar or novel object. After 1,2, and $3 \mathrm{~h}$ of reoxygenation, mice explored a novel object as if it were a familiar object $(51.8 \pm 5.7 \%, 61.6 \pm 6.2 \%$, and $72.6 \pm 3.6 \%$, respectively). Main effects of hypoxia ( $p<$ $0.001)$ and time $(p<0.001)$ were as follows: $0 \mathrm{~h}$ time point, $p<$ 0.001 , normoxic versus hypoxic $(82.5 \pm 1.9 \%$ vs $0 \pm 0 \%) ; 1 \mathrm{~h}$ time point, $p<0.001$, normoxic versus hypoxic $(79.2 \pm 1.6 \%$ vs $51.8 \pm 5.7 \%) ; 2 \mathrm{~h}$ time point, $p<0.001$, normoxic versus hypoxic $(81.9 \pm 2.1 \%$ vs $61.6 \pm 6.2 \%) ; 3 \mathrm{~h}$ time point, $p<0.05$, normoxic versus hypoxic ( $84.5 \pm 2.4 \%$ vs $72.6 \pm 3.6 \%)$. After 4,5 , and $6 \mathrm{~h}$ of reoxygenation, mice preferably explored the novel object over the familiar $(81.3 \%$ vs $18.7 \%, 77.5 \%$ vs $22.5 \%$, and $75.7 \%$ vs $24.3 \%$, respectively). Fig. $1 B$ shows that hypoxic mouse spontaneous locomotor activity was comparable to that of normoxic mice after $2 \mathrm{~h}$ of reoxygenation. Main effects of hypoxia $(p<$ $0.05)$ and time $(p<0.05)$ were as follows: $0 \mathrm{~h}$ time point, $p<$ 0.001 , normoxic versus hypoxic $(1910.4 \pm 128.9 \mathrm{~cm}$ vs $314.7 \pm$ $159.1 \mathrm{~cm}) ; 1 \mathrm{~h}$ time point, $p<0.05$, normoxic versus hypoxic $(1772.5 \pm 128.5 \mathrm{~cm}$ vs $1297.7 \pm 115.3 \mathrm{~cm})$.

\section{Memory formation recovers more slowly than memory recall after acute hypoxia}

Figure $2 \mathrm{~A}$ illustrates that if memory formation occurs after hypoxia (training), the ability of mice to learn does not recover until $6 \mathrm{~h}$ of reoxygenation $(66.2 \pm 1.0 \%$ vs $76.3 \pm 1.8 \%)$. At 3,4 , and $5 \mathrm{~h}$ of reoxygenation, mice exposed to hypoxia explored a novel object: $54.3 \pm 0.8 \%, 57.0 \pm 2.4 \%$, and $55.9 \pm 1.5 \%$, respectively. Main effects of groups $(p<0.001)$ were as follows: normoxic 

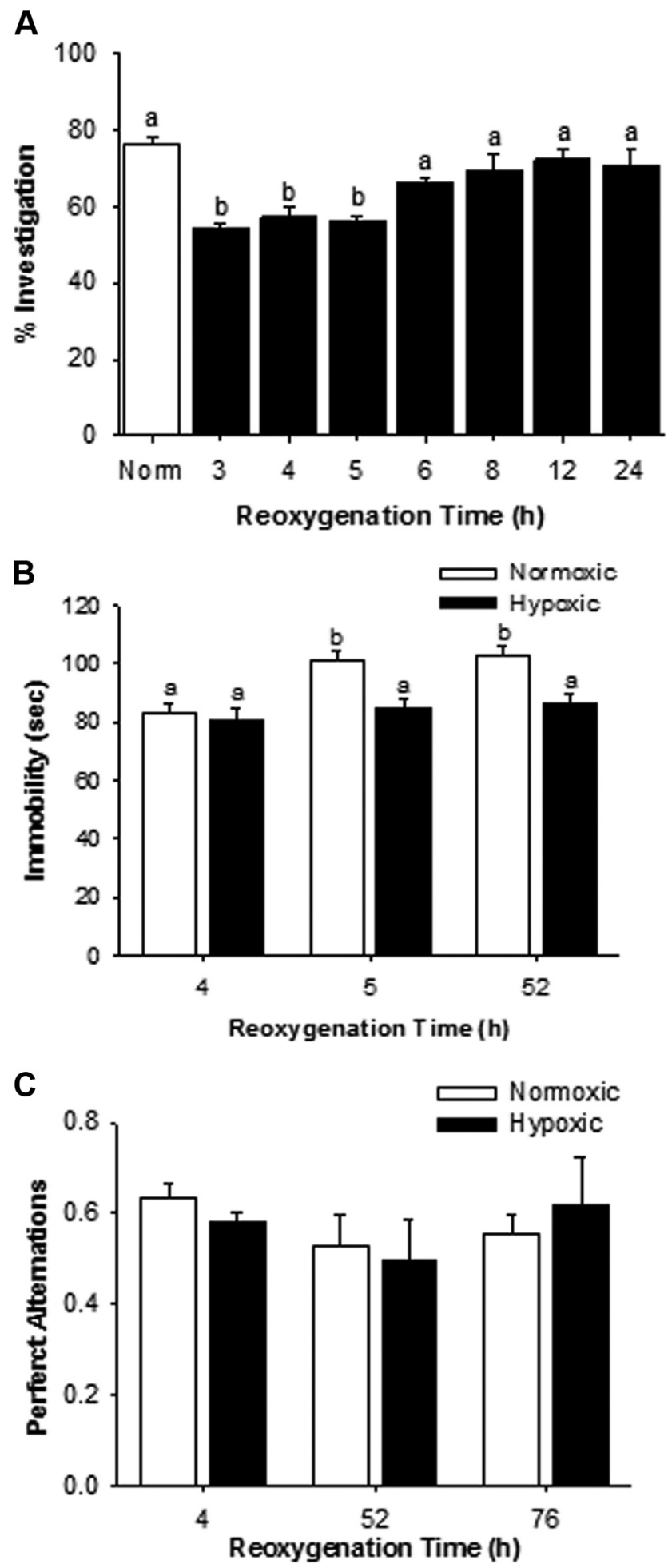

Figure 2. Memory formation recovers more slowly than memory recall after acute hypoxia. $\boldsymbol{A}$, Wild-type mice were exposed to normoxia (Norm) or hypoxia for $2 \mathrm{~h}$. After hypoxia, mice were trained in memory formation using novel object recognition $1 \mathrm{~h}$ before the time points indicated. Memory recall (percent investigation) was measured at the reoxygenation time points indicated. Results are expressed as means \pm SEM; $n=6-8$. Bars without a common superscript are different $(p<0.05)$. B, Mice were treated as in $\boldsymbol{A}$. Mice were trained in memory formation using cued fear conditioning after $4 \mathrm{~h}$ of reoxygenation. Memory recall (immobility) was measured after 5 and $52 \mathrm{~h}$ of reoxygenation. Results are expressed as means $\pm S E M ; n=$ 4. Bars without a common superscript are different $(p<0.05)$. C, Mice were treated as in $\boldsymbol{A}$. Perfect alternations were measured after 4,52 , and $76 \mathrm{~h}$ of reoxygenation. Results are expressed as means $\pm \mathrm{SEM} ; n=4$. versus $3 \mathrm{~h}$ time point, $p<0.001(75.3 \pm 1.9 \%$ vs $54.3 \pm 0.8 \%)$; normoxic versus $4 \mathrm{~h}$ time point, $p<0.001(75.3 \pm 1.9 \%$ vs $57.0 \pm$ $2.47 \%)$; normoxic versus $5 \mathrm{~h}$ time point, $p<0.001(75.3 \pm 1.9 \%$ vs $55.9 \pm 1.5 \%)$. Data were transformed. Fig. $2 B$ confirms that memory formation after hypoxia is impaired. In the cued fear conditioning test, both normoxic and hypoxic mice (after $4 \mathrm{~h}$ of reoxygenation) had similar immobility when first exposed to cue/ foot shock (training). When retested with just the cue (testing), after 5 and $52 \mathrm{~h}$ of reoxygenation, normoxic mice demonstrated a 121.9 and $123.8 \%$ increase in immobility, respectively, when compared to the initial cue/foot shock exposure (training). In contrast, hypoxic mice, when retested with just the cue at 5 and $52 \mathrm{~h}$ of reoxygenation, showed immobility comparable to that of the initial cue/foot shock exposure (training). Main effects of hypoxia $(p<0.001)$ and time $(p<0.05)$ were as follows: $4 \mathrm{~h}$ time point, $p<0.659$, normoxic versus hypoxic ( $83.0 \pm 3.7$ s vs $80.7 \pm$ $4.4 \mathrm{~s}) ; 5 \mathrm{~h}$ time point, $p<0.05$, normoxic versus hypoxic (101.1 \pm $3.3 \mathrm{~s}$ vs $84.8 \pm 3.1 \mathrm{~s})$; $52 \mathrm{~h}$ time point, $p<0.05$, normoxic versus hypoxic $(102.7 \pm 3.3 \mathrm{~s}$ vs $86.2 \pm 3.6 \mathrm{~s})$. Figure $2 C$ shows that perfect alternations in a spatially cued $\mathrm{Y}$-maze were not affected by hypoxia at 4,52 , and $76 \mathrm{~h}$ after reoxygenation. Main effects of hypoxia and time were $p=0.626$ and $p=0.235$.

\section{Knockout of IL-1R1 improves memory formation and locomotion while blunting activation of ERK1/2 and p38 MAPK}

Figure $3 A$ demonstrates that if memory formation (training) occurred $4 \mathrm{~h}$ after hypoxia, IL-1R1 KO mice had accelerated recovery of memory formation. At $5 \mathrm{~h}$ of reoxygenation, hypoxic IL-1R1 KO mice explored a novel object similar to normoxic wild-type (WT) mice $(70.2 \pm 7.4 \%$ vs $63.5 \pm 3.1 \%)$. Hypoxic WT mice explored a novel object as if it were a familiar object (47.9 \pm $4.7 \%)$. Main effects of genotype $(p<0.05)$ and hypoxia $(p=$ 0.235 ) were as follows: normoxic WT versus hypoxic WT, $p<$ 0.05 (63.5 $\pm 3.1 \%$ vs $47.9 \pm 4.7 \%)$; normoxic IL-1R1 KO versus hypoxic IL-1R1 KO, $p=0.645(66.9 \pm 3.3 \%$ vs $70.2 \pm 7.4 \%)$; hypoxic WT versus hypoxic IL-1R1 KO, $p<0.05$ (47.9 $\pm 4.7 \%$ vs $70.2 \pm 7.4 \%)$. Similar results were seen in mice administered IL-1 RA (Fig. 3B) [main effects of treatment $(p<0.05)$ and hypoxia $(p=0.055)$ : saline normoxic vs saline hypoxic, $p<0.05$ (66.9 \pm $5.3 \%$ vs $53.2 \pm 5.3 \%)$; IL-1RA normoxic vs IL-1RA hypoxic, $p=$ 0.457 (72.1 $\pm 3.4 \%$ vs $67.2 \pm 4.0 \%)$; saline hypoxic vs IL-1RA hypoxic, $p<0.05(53.2 \pm 5.3 \%$ vs $67.2 \pm 4.0 \%)]$ and in mice administered Ac-YVAD-CMK (Fig. 3C) [main effects of treatment $(p<0.05)$ and hypoxia $(p=0.5)$ : PBS normoxic vs PBS hypoxic, $p<0.05(69.7 \pm 3.5 \%$ vs $55.7 \pm 4.2 \%)$; Ac-YVAD normoxic vs Ac-YVAD hypoxic, $p=0.157$ (67.1 $\pm 3.3 \%$ vs $75.5 \pm 5.0 \%)$; PBS hypoxic vs Ac-YVAD hypoxic, $p<0.05$ $(55.7 \pm 4.2 \%$ vs $75.5 \pm 5.0 \%)]$. Fig. $3 D$ illustrates that spontaneous locomotor activity of IL-1R1 KO mice was restored after $1 \mathrm{~h}$ of reoxygenation as opposed to $2 \mathrm{~h}$ in hypoxic WT mice. Main effects of hypoxia $(p<0.001)$, genotype $(p=0.781)$, and time $(p=0.193)$ were as follows: $0 \mathrm{~h}$ time point: normoxic WT versus hypoxic WT, $p<0.001(2202.2 \pm 109.2 \mathrm{~cm}$ vs $936.2 \pm 267.6 \mathrm{~cm})$; normoxic IL-1R1 KO versus hypoxic IL-1R1 KO, $p<0.001$ $(2068.5 \pm 40.0 \mathrm{~cm}$ vs $535.0 \pm 260.5 \mathrm{~cm})$; normoxic WT versus normoxic IL-1R1 KO, $p=0.695(2202.2 \pm 109.2 \mathrm{~cm}$ vs $2068.5 \pm$ $40.0 \mathrm{~cm}$ ); hypoxic WT versus hypoxic IL-1R1 KO, $p=0.165$ $(936.2 \pm 267.6 \mathrm{~cm}$ vs $535.0 \pm 260.5 \mathrm{~cm}) ; 1 \mathrm{~h}$ time point: normoxic WT versus hypoxic WT, $p<0.05(1989.1 \pm 132.5 \mathrm{~cm}$ vs $1283.3 \pm 132.1 \mathrm{~cm})$; normoxic IL-1R1 KO versus hypoxic IL-1R1 $\mathrm{KO}, p=0.546(1417.1 \pm 223.1 \mathrm{~cm}$ vs $1615.6 \pm 140.1 \mathrm{~cm})$; normoxic WT versus normoxic IL-1R1 KO, $p=0.111(1989.1 \pm$ 


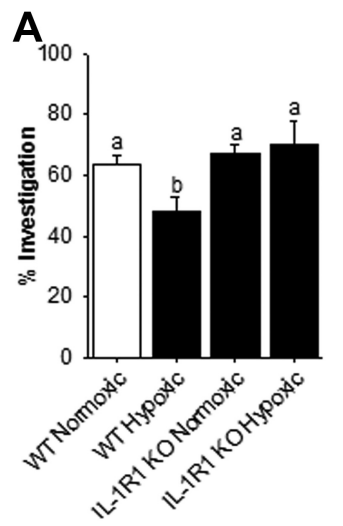

$\mathbf{B}_{100}$

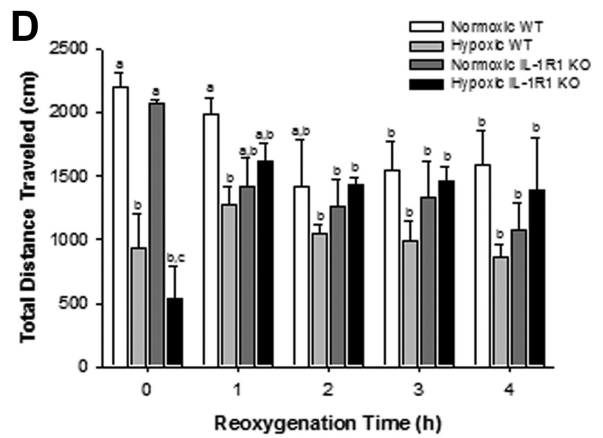

Figure 3. Knockout of IL-1R1 improves memory formation and locomotion while blunting activation of ERK1/2 and p38 MAPK. $A$, WT or IL-1R1 K0 mice were exposed to normoxia or hypoxia for $2 \mathrm{~h}$. Mice were trained in memory formation using novel object recognition after $4 \mathrm{~h}$ of reoxygenation. Memory recall (percent investigation) was measured after $5 \mathrm{~h}$ of reoxygenation. Results are expressed as means $\pm \mathrm{SEM} ; n=4$. Bars without a common superscript are different $(p<0.05)$. $\boldsymbol{B}$, WT mice treated with/without intraperitoneal IL-1RA were exposed to normoxia or hypoxia as in $\boldsymbol{A}$, and memory was tested as in $\boldsymbol{A}$. Results are expressed as means $\pm \mathrm{SEM} ; n=6$. Bars without a common superscript are different $(p<0.05)$. C, WT mice treated with/without intracerebroventricular AC-YVAD-CMK were exposed to normoxia or hypoxia as in $\boldsymbol{A}$, and memory was tested as in $\boldsymbol{A}$. Results are expressed as means $\pm \mathrm{SEM} ; n=6$. Bars without a common superscript are different $(p<0.05)$. D, WT or IL-1R1 K0 mice were treated as in $A$, and spontaneous locomotor activity (total distance traveled) was measured at the reoxygenation time points indicated. Results are expressed as means $\pm \mathrm{SEM} ; n=4$. Bars without a common superscript are different $(p<0.05)$. $E$, WT and IL-1R1 KO mice were exposed to normoxia or hypoxia as in $\boldsymbol{A}$. Brain p-pERK1/2, p-p38 MAPK, and p-JNK were measured $1 \mathrm{~h}$ after hypoxia. Results are expressed as means \pm SEM; $n=6-9$. Bars without a common superscript are different $(p<0.05)$.

$132.5 \mathrm{~cm}$ vs $1417.1 \pm 223.1 \mathrm{~cm})$; hypoxic WT versus hypoxic IL-1R1 KO, $p=0.245(1283.3 \pm 132.1 \mathrm{~cm}$ vs $1615.6 \pm 140.1 \mathrm{~cm})$. Fig. $3 E$ shows that after $1 \mathrm{~h}$ of reoxygenation, ERK1/2 (normoxic vs hypoxic: $1.0 \pm 0.2$-fold vs $1.4 \pm 0.1$-fold; $p=0.05)$ and $\mathrm{p} 38$ MAPK (normoxic vs hypoxic: $1.0 \pm 0.2$-fold vs $1.5 \pm 0.2$-fold; $p=0.05)$ were activated in the brains of WT but not IL-1R1 KO mice ( $p=0.94$ and $p=0.91$, respectively). In contrast, JNK was not significantly activated in either WT or IL-1R1 KO $1 \mathrm{~h}$ after reoxygenation.

\section{AR blockade prevents hypoxia-dependent activation of caspase 1 in the brain}

Figure $4 A$ shows that after $1 \mathrm{~h}$ of reoxygenation, brain caspase 1 is $208.8 \%$ more active in hypoxic mice than in normoxic mice. Hypoxic mice not allowed to significantly reoxygenate did not demonstrate an increase in brain caspase 1 activity. In addition, after $6 \mathrm{~h}$ of reoxygenation, brain caspase 1 activity was similar to that of normoxic mice: $0 \mathrm{~h}$ time point: $p=0.525$, normoxic versus hypoxic $(1.0 \pm 0.1$-fold vs $1.1 \pm 0.2$-fold $) ; 1 \mathrm{~h}$ time point: $p<0.001$, normoxic versus hypoxic $(1.0 \pm 0.2$-fold vs $2.1 \pm$ 0.2 -fold); 6 h time point: $p=0.930$, normoxic versus hypoxic $(1.0 \pm 0.1$-fold vs $1.0 \pm 0.1$-fold). Figure $4, B$ and $C$, illustrates that mice pretreated with either caffeine or an A1/A2A AR inhibitor cocktail did not upregulate caspase 1 activity in the brain after
$1 \mathrm{~h}$ of reoxygenation [saline hypoxic vs caffeine hypoxic: $p<0.001(2.6 \pm 0.0-$ fold vs $1.0 \pm 0.2$-fold); vehicle hypoxic vs A1/A2A antagonist (antag) hypoxic: $p<$ $0.05(2.6 \pm 0.3$-fold vs $1.5 \pm 0.1$-fold $)]$. Table 1 demonstrates that after $1 \mathrm{~h}$ of reoxygenation, hypoxia lowers the brain GSH/GSSG ratio by $49 \%(p<0.05)$ and that caffeine and NAC each prevented this decline. The GSH/GSSG ratio was unchanged if hypoxic mice were not afforded significant time to reoxygenate $(1.00 \pm 0.22$-fold vs $1.02 \pm 0.22$-fold, normoxia vs hypoxia; $p=0.832$ ). Importantly, NAC-pretreated mice did not lose the ability to upregulate brain caspase 1 activity after reoxygenation (Fig. 4D). Main effects of treatment $(p=0.358)$ and hypoxia $(p<0.001)$ were as follows: saline normoxic versus saline hypoxic: $p<$ 0.05 (1.0 \pm 0.0 -fold vs $2.1 \pm 0.5$-fold); NAC normoxic versus NAC hypoxic: $p<$ 0.05 (1.24 \pm 0.2 -fold vs $2.2 \pm 0.4$-fold); saline hypoxic versus NAC hypoxic: $p=$ 0.498 (2.1 \pm 0.5 -fold vs $2.2 \pm 0.4$-fold). Fig. $4 E$ shows that mice perfused with 30 , 50 , and $100 \mu \mathrm{M}$ adenosine have a $167 \%$, $225 \%$, and $247 \%$ increase in brain caspase 1 activity, respectively. PBS perfused versus adenosine perfused. Main effect of treatment $(p<0.001)$ is as follows: $0 \mu \mathrm{M}$ versus $10 \mu \mathrm{M}, p=0.844(1.0 \pm 0.1$ vs $0.8 \pm 0.1) ; 0 \mu \mathrm{M}$ versus $30 \mu \mathrm{M}, p<0.05$ $(1.0 \pm 0.1$ vs $1.6 \pm 0.2) ; 0 \mu \mathrm{M}$ versus 50 $\mu \mathrm{M}, p<0.001(1.0 \pm 0.1$ vs $2.3 \pm 0.3) ; 0$ $\mu \mathrm{M}$ versus $100 \mu \mathrm{M}, p<0.001(1.0 \pm 0.1 \mathrm{vs}$ $2.5 \pm 0.1) ; 10 \mu \mathrm{M}$ versus $30 \mu \mathrm{M}, p=0.01$ $(0.8 \pm 0.1$ vs $1.6 \pm 0.2) ; 10 \mu \mathrm{M}$ versus 50 $\mu \mathrm{M}, p<0.001(0.8 \pm 0.1$ vs $2.3 \pm 0.3) ; 10$ $\mu \mathrm{M}$ versus $100 \mu \mathrm{M}, p<0.001(0.8 \pm 0.1$ vs $2.5 \pm 0.1) ; 30 \mu \mathrm{M}$ versus $50 \mu \mathrm{M}, p=0.075$ ( $1.6 \pm 0.2$ vs $2.3 \pm 0.3) ; 30 \mu \mathrm{M}$ versus 100 $\mu \mathrm{M}, p=0.023(1.6 \pm 0.2$ vs $2.5 \pm 0.1) ; 50 \mu \mathrm{M}$ versus $100 \mu \mathrm{M}, p=$ $0.940(2.3 \pm 0.3$ vs $2.5 \pm 0.1)$. Figure $4, F$ and $G$, demonstrate that caffeine but not NAC inhibits adenosine-dependent activation of caspase 1 when adenosine is perfused into mice (Fig. $4 F$, main effect of treatment, $p<0.001)$ as follows: PBS versus adenosine, $p<0.001$ ( $1.0 \pm 0.1$ vs $1.9 \pm 0.1$ ); adenosine versus caffeine, $p<$ 0.001 ( $1.9 \pm 0.1$ vs $0.9 \pm 0.1$ ); adenosine versus adenosine plus caffeine, $p<0.001$ ( $1.9 \pm 0.1$ vs $1.3 \pm 0.1)$; adenosine plus caffeine versus caffeine, $p=0.06(0.9 \pm 0.1$ vs $1.3 \pm 0.1)$; PBS versus adenosine plus caffeine, $p=0.267(1.0 \pm 0.1$ vs $1.3 \pm 0.1)$; PBS versus caffeine, $p=0.841(1.0 \pm 0.1$ vs $0.9 \pm 0.1)$. In Figure $4 G$, the main effect of treatment $(p<0.05)$ is as follows: PBS versus adenosine, $p<0.05(1.0 \pm 0.0$ vs $1.9 \pm 0.1)$; adenosine versus NAC, $p<0.05$ (1.9 \pm 0.1 vs $1.2 \pm 0.3)$; adenosine versus adenosine plus NAC, $p=0.991(1.9 \pm 0.1$ vs $1.8 \pm 0.1)$; adenosine plus NAC versus NAC, $p=0.076(1.8 \pm 0.1$ vs $1.2 \pm 0.3)$; PBS versus adenosine plus NAC, $p<0.05(1.0 \pm 0.0$ vs $1.8 \pm 0.1)$; PBS versus NAC: $p=0.897(1.0 \pm 0.0$ vs $1.2 \pm 0.3)$. Finally, to examine another potential activator of the inflammasome, uric acid was examined. After $1 \mathrm{~h}$ of reoxygenation, serum uric acid levels were similar in normoxic and hypoxic mice $(3.3 \pm 0.4$ $\mathrm{mg} / \mathrm{dl}$ vs $3.1 \pm 0.2 \mathrm{mg} / \mathrm{dl})$. 
Hypoxia induces brain region-specific activation of caspase 1

Figure $5 A$ shows that $1 \mathrm{~h}$ after hypoxia/ reoxygenation, caspase 1 activity in the amygdala compared to control was increased $180 \%$ (normoxic vs hypoxic, $1.0 \pm$ 0.1 vs $1.8 \pm 0.1, p<0.001)$. Hippocampal caspase 1 activity was not impacted by hypoxia/reoxygenation (normoxic vs hypoxic, $1.0 \pm 0.1$ vs $0.7 \pm 0.1, p=0.134)$, and neither was prefrontal cortex or cerebellar caspase 1 activity (data not shown). To determine whether significant gliosis occurred after hypoxia, immunohistochemistry for GFAP was performed. Fig. $5 B$ demonstrates no change in GFAP expression at 1 and $6 \mathrm{~h}$ of reoxygenation in both WT and IL-1R1 KO mice. Additionally, qPCR for GFAP and aquaporin 4 gene transcripts were examined in the amygdala and hippocampus at 1 and $6 \mathrm{~h}$ after reoxygenation in WT and IL-1R1 KO mice, revealing no impact of hypoxia (data not shown). To examine microglia infiltration/proliferation/activation, gene transcripts for CD11b, F4/80, and PBR were examined in the amygdala and hippocampus after 1 and $6 \mathrm{~h}$ of reoxygenation in WT and IL-1R1 KO mice. No differences were observed (data not shown).

\section{AR blockade speeds recovery of memory formation after hypoxia}

Figure $6 \mathrm{~A}$ demonstrates that if memory formation (training) occurred $4 \mathrm{~h}$ after hypoxia, mice administered caffeine had accelerated recovery of memory formation. At $5 \mathrm{~h}$ of reoxygenation, hypoxic mice pretreated with caffeine explored a novel object similarly as normoxic mice $(68.0 \pm 3.6 \%$ vs $69.5 \pm 5.6 \%)$. Hypoxic mice with a preadministered vehicle explored a novel object as if it were a familiar object $(48.6 \pm 2.4 \%)$. Main effects of treatment $(p<0.05)$ and hypoxia $(p<0.05)$ were as follows: saline normoxic versus saline hypoxic, $p<0.05$ $(69.5 \pm 5.6 \%$ vs $48.6 \pm 2.4 \%)$; caffeine normoxic versus caffeine hypoxic, $p=0.838$ $(69.2 \pm 4.6 \%$ vs $68.0 \pm 3.6 \%)$; saline hypoxic versus caffeine hypoxic, $p<0.05$ $(48.6 \pm 2.4 \%$ vs $68.0 \pm 3.6 \%)$. Fig. $6 \mathrm{~B} \mathrm{dem-}$ onstrates that if memory formation (training) occurred $4 \mathrm{~h}$ after hypoxia, mice administered 8-cyclopentyl-1,3-dipropylxanthine plus 3,7-dimethyl-1-propargylxanthine had accelerated recovery of memory formation. At $5 \mathrm{~h}$ of reoxygenation, hypoxic mice pretreated with 8-cyclopentyl-1,3dipropylxanthine plus 3,7-dimethyl-1propargylxanthine explored a novel object similarly as normoxic mice $(76.1 \pm 3.7 \%$ vs $73.5 \pm 3.4 \%)$. Hypoxic mice preadministered vehicle explored a novel object as if it were a familiar object $(62.4 \pm 3.2 \%)$. Main
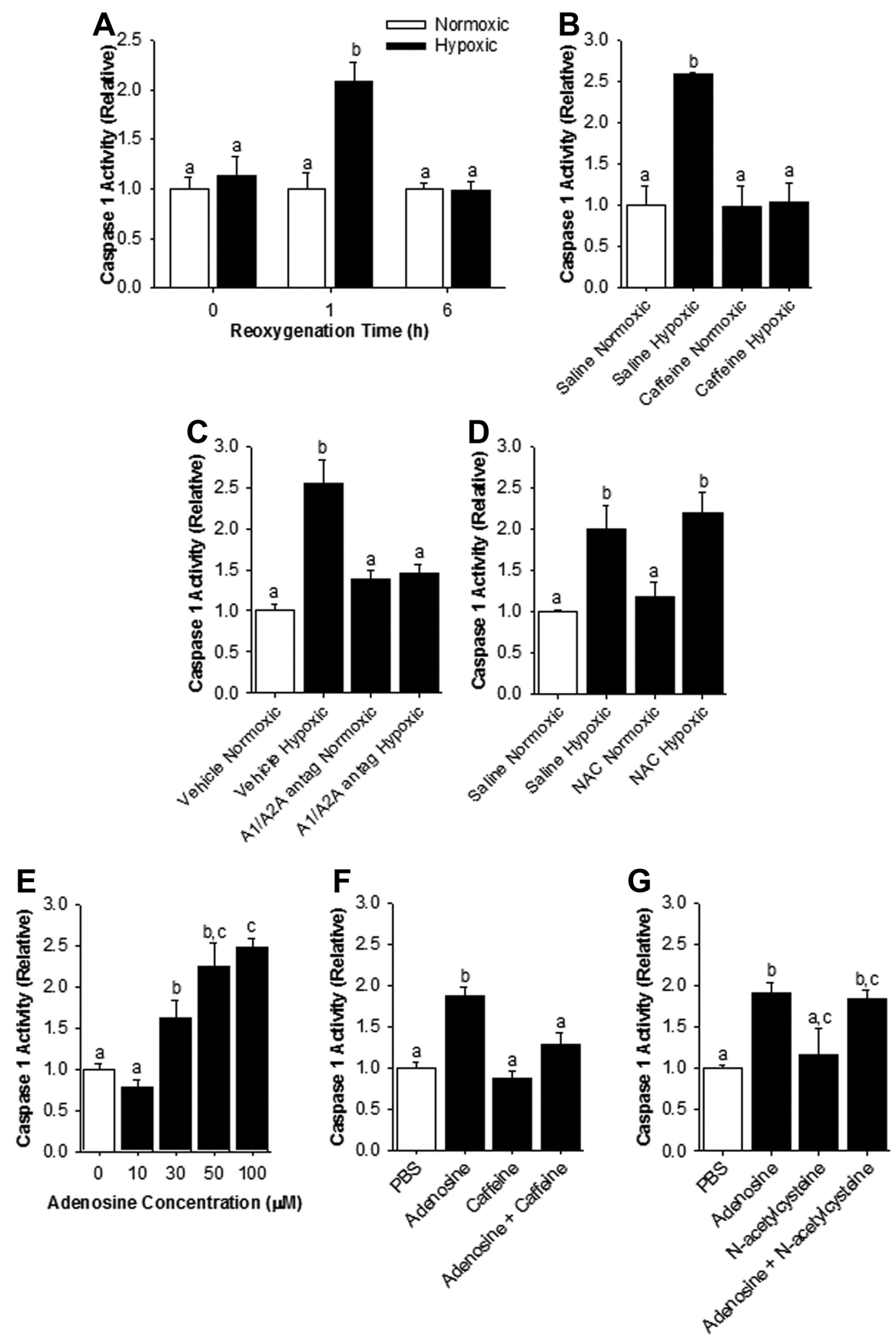

Figure 4. AR blockade prevents hypoxia-dependent activation of caspase 1 in the brain. $\boldsymbol{A}$, Wild-type mice were exposed to normoxia or hypoxia for $2 \mathrm{~h}$. Caspase 1 activity was measured at the reoxygenation time points indicated. Results are expressed as means $\pm \mathrm{SEM} ; n=4$. Bars without a common superscript are different $(p<0.05)$. $\boldsymbol{B}$, Wild-type mice treated with/without caffeine were exposed to normoxia or hypoxia as in $\boldsymbol{A}$, and caspase 1 activity measured $1 \mathrm{~h}$ after reoxygenation. Results are expressed as means $\pm \mathrm{SEM} ; n=4$. Bars without a common superscript are different $(p<0.05)$. $\boldsymbol{C}$, Wild-type mice treated with/without 8-cyclopentyl-1,3-dipropylxanthine plus 3,7-dimethyl-1-propargylxanthine (A1/A2A antag) were exposed to normoxia or hypoxia as in $\boldsymbol{A}$, and caspase 1 activity was measured $1 \mathrm{~h}$ after reoxygenation. Results are expressed as means $\pm \mathrm{SEM} ; n=$ 4. Bars without a common superscript are different $(p<0.05)$. $\boldsymbol{D}$, Wild-type mice treated with/without NAC were exposed to normoxia or hypoxia as in $\boldsymbol{A}$, and caspase 1 activity was measured $1 \mathrm{~h}$ after reoxygenation. Results are expressed as means $\pm \mathrm{SEM}$; $n=6$. Bars without a common superscript are different $(p<0.05)$. $\boldsymbol{E}$, Wild-type mice were perfused with the adenosine concentrations indicated. Caspase 1 activity was measured $1 \mathrm{~h}$ after perfusion. Results are expressed as means $\pm S E M ; n=6$. Bars without a common superscript are different $(p<0.05)$. $\boldsymbol{F}$, Wild-type mice were perfused with/without $50 \mu m$ adenosine plus 500 $\mu \mathrm{m}$ caffeine. Caspase 1 activity was measured $1 \mathrm{~h}$ after perfusion. Results are expressed as means $\pm S E M ; n=6$. Bars without a common superscript are different $(p<0.05)$. G, Wild-type mice were perfused with/without $50 \mu \mathrm{m}$ adenosine plus $500 \mu \mathrm{M}$ NAC. Caspase 1 activity was measured $1 \mathrm{~h}$ after perfusion. Results are expressed as means $\pm \mathrm{SEM} ; n=6$. Bars without a common superscript are different $(p<0.05)$. 
Table 1. Impact of reoxygenation on the glutathione to glutathione disulfide ratio in the brain

\begin{tabular}{lll}
\hline Treatment & Normoxic & Reoxygenation (1 h) \\
\hline Saline & $1.00 \pm 0.21^{a}$ & $0.49 \pm 0.12^{b}$ \\
Caffeine & $0.88 \pm 0.15^{a}$ & $0.87 \pm 0.10^{a}$ \\
NAC & $0.82 \pm 0.02^{a}$ & $1.03 \pm 0.03^{a}$ \\
\hline
\end{tabular}

Wild type mice were exposed to normoxia or hypoxia for $2 \mathrm{~h}$. Whole brains were harvested and analyzed for GSH and GSSG concentrations. Results are expressed as relative change in GSH/GSSG ratio, means $\pm S E M ; n=4$. Results within individual rows without a common superscript are different $(p<0.05)$. effects of treatment $(p=0.055)$ and hypoxia $(p=0.197)$ (hypoxia $\times$ treatment, $p<0.05$ ) were as follows: vehicle normoxic versus vehicle hypoxic, $p<0.05$ (73.7 $\pm 2.7 \%$ vs $62.4 \pm 3.2 \%)$, 8 -cyclopentyl-1,3-dipropylxanthine plus 3, 7-dimethyl-1-propargylxanthine normoxic versus 8-cyclopentyl-1,3-dipropylxanthine plus 3,7-dimethyl-1-propargylxanthine hypoxic, $p=0.583(73.5 \pm 3.4 \%$ vs $76.1 \pm 3.7 \%)$; vehicle hypoxic versus 8 -cyclopentyl-1,3-dipropylxanthine plus 3,7-dimethyl-1-propargylxanthine hypoxic, $p<0.05$ $(62.4 \pm 3.2 \%$ vs $76.1 \pm 3.7 \%)$.

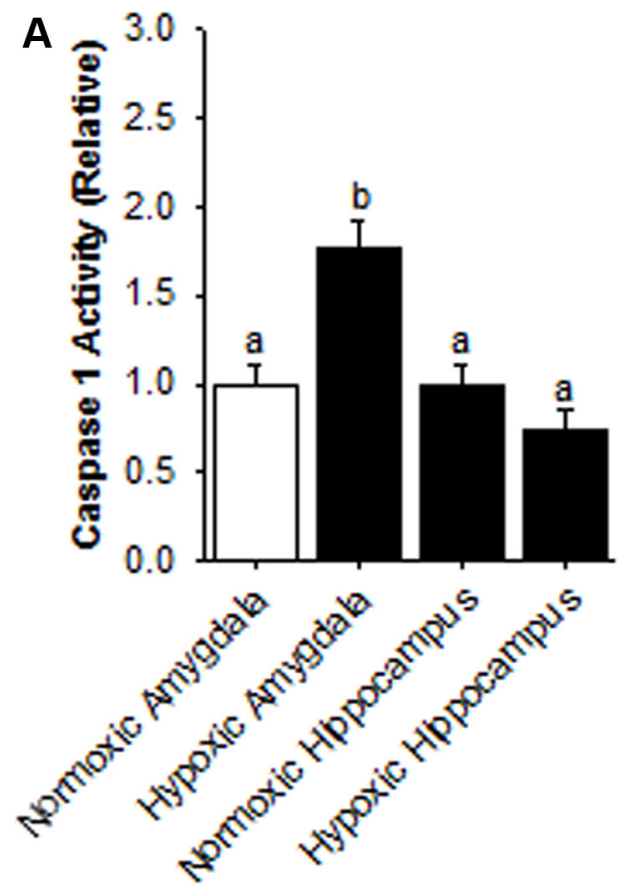

B
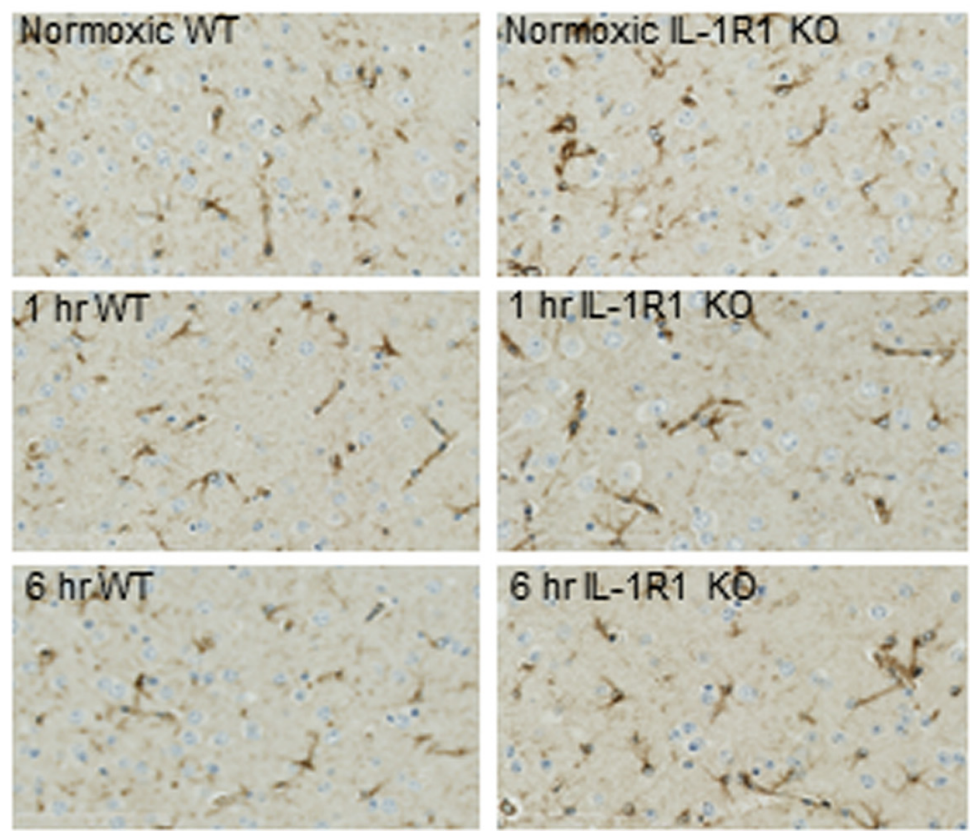

Figure 5. Hypoxia induces brain region-specific activation of caspase 1. $\boldsymbol{A}$, Wild-type mice were exposed to normoxia or hypoxia for $2 \mathrm{~h}$. Caspase 1 activity was measured in the amygdala and hippocampus $1 \mathrm{~h}$ after reoxygenation Results are expressed as means \pm SEM; $n=4$. Bars without a common superscript are different $(p<0.05)$. $\boldsymbol{B}$, WT mice and IL-1R1 K0 mice were treated as in $\boldsymbol{A}$. Immunohistochemistry was performed for GFAP at 1 and $6 \mathrm{~h}$ after reoxygenation. Representative images of the amygdala $(n=3)$.

\section{Discussion}

In humans, the causes of a confusional state are numerous and include drugs, toxins, infections, head injuries, and metabolic derangements (Gascon and Barlow, 1970; Mori and Yamadori, 1987). Hypoxemia is a well recognized antecedent to brain injury (Rees et al., 1998) that can precipitate memory loss well beyond hypoxemia-associated confusion or delirium (Berggren et al., 1987). In rodents, hypoxia has long been known to cause retrograde amnesia (Sara and Lefevre, 1972). The inability of rodents to recall a previously learned task or avoid noxious stimuli after hypoxia can be long lived $(24 \mathrm{~h})$ as Sara et al. show in rats exposed to $3.5 \%$ oxygen (Sara and Lefevre, 1972). In addition, this memory loss can occur without significant brain cell death in mice because, as Kyff et al. (1989) show and we confirm, $2 \mathrm{~h}$ of hypoxia above $5 \%$ oxygen does not lead to identifiable neuronal death even in the hippocampus (Johnson et al., 2007). Here we show that the acute hypoxia used induced minimal neuroinflammation over the $6 \mathrm{~h}$ examined as reflected by no change in the gene expression of GFAP, aquaporin 4, CD11b, F4/ 80 , and PBR and no change in GFAP protein expression. These findings indicate that unlike ischemia where all of the aforementioned astrocyte and microglial markers are rapidly upregulated (Feuerstein et al., 1997, Lu and Sun, 2003, Natale et al., 2003, Taguchi et al., 2007, Taniguchi et al., 2007, Xiong et al., 2009) and significant gliosis occurs, acute hypoxia can be a recoverable event that results in negligible neuropathology.

The mechanism protecting burrowing mammals [especially certain moles that can survive severe oxygen deprivation $(3 \%)$ for extended times $(8 \mathrm{~h})$; Avivi et al., 2006] from acute hypoxia is not clear, but its origin, evolutionarily, appears as a safeguard to burrow collapse. As Fig. $1 \mathrm{~A}$ shows, mice exposed to $6 \%$ hypoxia for $2 \mathrm{~h}$ developed retrograde amnesia that resolved after $4 \mathrm{~h}$ of reoxygenation. This loss of memory was not due solely to a motor deficit that prevented mice from performing the task, be- 
A

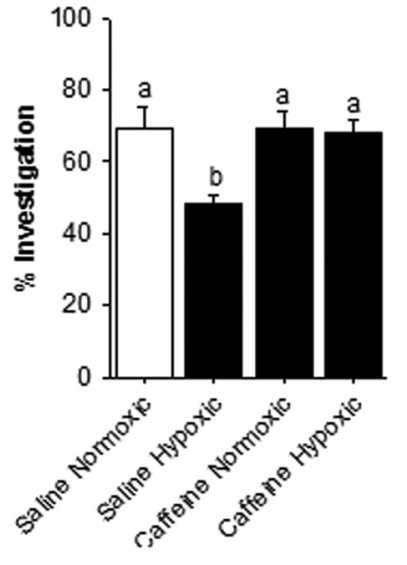

B

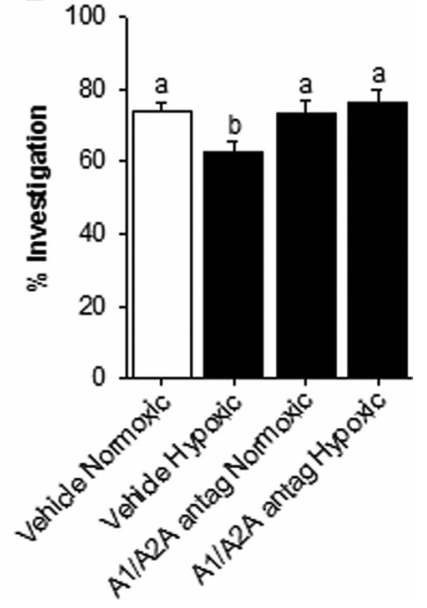

Figure 6. AR blockade speeds recovery of memory formation after hypoxia. $\boldsymbol{A}$, Wild-type mice treated with/without caffeine were exposed to normoxia or hypoxia for $2 \mathrm{~h}$. Mice were trained in memory formation using novel object recognition after $4 \mathrm{~h}$ of reoxygenation. Memory recall (percent investigation) was measured after $5 \mathrm{~h}$ of reoxygenation. Results are expressed as means \pm SEM; $n=6$. Bars without a common superscript are different $(p<0.05)$. $\boldsymbol{B}$, Wildtype mice treated with/without 8-cyclopentyl-1,3-dipropylxanthine plus 3,7-dimethyl-1propargylxanthine (A1/A2A antag) were exposed to normoxia or hypoxia as in $\boldsymbol{A}$, and memory was tested as in $\boldsymbol{A}$. Results are expressed as means $\pm \mathrm{SEM} ; n=6$. Bars without a common superscript are different $(p<0.05)$.

cause mice had regained normal locomotor activity after $2 \mathrm{~h}$ of reoxygenation (Fig. $1 B$ ).

Post-hypoxia, the ability of mice to form a new memory did not recover until after $6 \mathrm{~h}$ of reoxygenation (Fig. $2 A$ ). Since the training phase for novel object recognition occurred $1 \mathrm{~h}$ before the testing phase, memory formation after hypoxia was impaired within the first $5 \mathrm{~h}$ of reoxygenation. To determine whether the results obtained were memory type specific, cued fear conditioning and spatially cued Y-maze performance were used as additional tests of memory dysfunction. Fig. $2 B$ illustrates that with cued fear conditioning, mice failed to learn when trained after $4 \mathrm{~h}$ of reoxygenation and that this was a failure of memory formation and not a deficiency in task performance because, even after $52 \mathrm{~h}$ of reoxygenation, mice did not recall the learned cue. Unlike fear conditioning, mouse performance in a spatially cued Y-maze was not impacted by hypoxia (Fig. 2C), demonstrating spatial memory, and hence the hippocampus may be less impacted by hypoxia.

Although hypoxia appears tied to anterograde amnesia in humans (Beatty et al., 1987), almost no work has been performed in animal models. A single study by Udayabanu et al. (2008) looked at retrograde and anterograde memory in a mouse model of acute hypobaric hypoxia with a calculated oxygen percentage of $7 \%$ (307.4 Torr) for $6 \mathrm{~h}$. They concluded that hypoxia only impacted retrograde memory and not anterograde memory. While they conducted memory formation $2 \mathrm{~h}$ post-hypoxia, the tests they used (passive avoidance step-through and elevated plus maze) were strongly dependent on spatial memory and, thus, the hippocampus (Rodgers et al., 1997; Yirmiya et al., 2002). Likewise, in our study spatially cued Y-maze performance was not affected by hypoxia, while our more amygdala-dependent tests (object recognition and cued fear conditioning) were (Moses et al., 2005). Interestingly, Broadbent et al. (2004) showed that in rats spatial memory was impaired when $30-50 \%$ of the dorsal hippocampus or $50 \%$ of the ventral hippocampus is damaged. Object recognition memory, however, was only impaired after $75-100 \%$ of the

dorsal hippocampus is injured (Broadbent et al., 2004). Taken together, these findings indicate that acute hypoxia impairs memory that is predominantly decoupled from the hippocampus. Support for this contention is seen in Fig. $5 A$, which illustrates that hypoxia/reoxygenation increases caspase 1 activation in the amygdala but not in the hippocampus.

Brain IL- $1 \beta$ is important to the recovery of memory formation after hypoxia. Fig. $3 C$ shows that the caspase 1 -specific inhibitor YVAD-CMK (Wu et al., 2010) administered intracerebroventricularly speeds the recovery of memory formation after hypoxia. Since caspase 1 can process other proteins besides pro-IL-1 $\beta$ (Keller et al., 2008), we confirmed these findings by administering IL-1 RA (Fig. 3B) and by using IL-1R1 KO mice (Fig. 3A). Since YVAD-CMK was administered intracerebroventricularly, our results indicate that brain-generated IL- $1 \beta$ is responsible for impairing memory formation after hypoxia as opposed to IL-1 from the peripheral blood. That a dysregulation in brain IL-1 negatively impacts certain aspects of memory is not surprising. IL-1 is best known for its role in hippocampaldependent memory (Goshen et al., 2007), and conditions that disrupt IL-1 signaling impair mouse water maze and passive avoidance performance (Yirmiya et al., 2002). As proposed by Goshen and Yirmiya (2002), hippocampal-dependent memory and plasticity are regulated by IL-1 in an inverted U-shaped correlation where low and high brain IL-1 signaling have similar impacts. As for the role of IL-1 in novel object recognition, little is known. Costello et al. (2011) just demonstrated that mice deficient in the single Ig-interleukin-1 related receptor have impaired novel object recognition as well as an upregulation of IL- $1 \alpha$, but not IL-1 $\beta$, in the brain (Costello et al., 2011). They propose that IL- $1 \alpha$ via IL-1R 1 may drive certain memory impairments, especially as related to infectious etiologies. Figure $3 E$ shows that in hypoxia, activation of ERK1/2 and p38 MAPK may be important to IL- 1 regulated memory, because $1 \mathrm{~h}$ after reoxygenation these kinases had reduced phosphorylation in IL-1R1 KO mice when compared to wild-type mice. Thus, our results suggest that IL- $1 \beta$ may be more important in disease states involving low oxygen and that MAPK superfamily members downstream of IL-1R1 may be regulatory.

As we and others have shown, brain IL- $1 \beta$ is elicited during activation of the neuroimmune system (Kostulas et al., 1999; Johnson et al., 2007; Dantzer et al., 2008). Basally, mature IL-1 $\beta$ is nearly undetectable in the rodent brain (Layé et al., 2000; Takao et al., 1993; Taupin et al., 1993), but with neuroimmune stimulation, especially ischemic injury, IL-1 $\beta$ is measurable (Saito et al., 1996) and promotes brain injury (Rothwell, 2003). How mature IL- $1 \beta$ is generated in the brain is unknown. Peripherally, the inflammasome is critical to caspase 1 activation, and caspase 1 is responsible for the final enzymatic cleavage of pro-IL- $1 \beta$ to secretable IL-1 $\beta$ (Lamkanfi et al., 2007). Fig. $4 A$ demonstrates that there is increased brain caspase 1 activity after hypoxia but that reoxygenation is important to this activity, because nonreoxygenated mice do no show increased caspase 1 activity. Since reoxygenation appears necessary to brain caspase 1 activation, we examined known danger signals potentially relevant to peripheral inflammasome activation and to hypoxia. ROS are considered to play a role in reoxygenation/reperfusion injury, and redox-dependent activation of the NLRP3 inflammasome has recently been shown (Martinon, 2010; Tschopp and Schroder, 2010). Table 1 demonstrates that hypoxia/reoxygenation markedly reduced the GSH/GSSG ratio indicative of ROS generation. As expected, administration of the GSH precursor and antioxidant NAC (Raju et al., 1994) before hypoxia prevented a hypoxia/ 
reoxygenation-dependent decline in the GSH/GSSG ratio. Additionally, caffeine, which has been shown to have antioxidant properties (Shi and Dalal, 1991; Devasagayam et al., 1996), also prevented a decline in the GSH/GSSG ratio after hypoxia/reoxygenation. Unexpectedly, caffeine (Fig. $4 B$ ) and more importantly antagonism of the A1+A2A ARs (Fig. 4C) prevented reoxygenation-dependent activation of caspase 1 while NAC did not (Fig. 4D). Furthermore, caffeine (Fig. 6A) and A1/A2A AR antagonism (Fig. $6 B$ ), but not NAC (data not shown), sped recovery from hypoxia-induced loss of memory formation. These findings indicate that adenosine triggers hypoxia/reperfusiondependent caspase 1 activation, resulting in a delay in the ability to form new memories. To further confirm that adenosine activates caspase 1 in the brain, mice were perfused with adenosine. Fig. $4 E$ shows that adenosine activates brain caspase 1 in a dosedependent manner and that the $\mathrm{EC}_{50}$ of $30 \mu \mathrm{M}$ is consistent with interstitial adenosine concentrations seen in the microenvironment of hypoxic tissue $(10-50 \mu \mathrm{M})$ (Sitkovsky and Lukashev, 2005). Figure 4, $F$ and $G$, demonstrates that caffeine but not NAC blocked adenosine-dependent activation of caspase 1, additionally illustrating that ARs but not ROS are important to adenosine-dependent caspase 1 activation.

To date, neither adenosine nor its receptors are implicated as direct activators of the inflammasome or of caspase 1. However, $\mathrm{AR}$ antagonism, especially via caffeine, is linked to cognitive improvement in certain neurodegenerative diseases (Cunha and Agostinho, 2010) and as a protectant against Alzheimer's disease (Cao et al., 2012). How caffeine achieves this function is unclear, but it has been postulated that since adenosine acts as an inhibitory neurotransmitter, the ability of caffeine to suppress this effect of adenosine is beneficial (Chen et al., 2001). The antioxidant qualities of caffeine have been postulated as a mechanism, but this theory is not consistent with the neuroprotection from ischemia afforded by receptor-specific AR antagonists that lack antioxidant properties (Phillis, 1995) or seen in A2A AR KO mice (Chen et al., 1999). Therefore, caffeine acting as an inhibitor of IL- $1 \beta$ generation, as implicated here, is a potentially new mechanism for its action.

How adenosine activates the inflammasome through ARs needs to be defined. Purines are metabolized to uric acid, which is a well described activator of the inflammasome (Pétrilli and Martinon, 2007). We measured serum uric acid after hypoxia and saw no increase after $1 \mathrm{~h}$ of reoxygenation. This finding is consistent with others who have seen that xanthine oxidase, which catalyzes the oxidation of hypoxanthine to xanthine and xanthine to uric acid, is increased after reoxygenation but only at more distant time points (Jones et al., 1968; González-Flecha and Cutrin, 1993; Poulsen et al., 1993; Cherubini et al., 2000). A potential mechanism by which ARs activate caspase 1 is through $\mathrm{K}^{+}$flux. When triggered by high extracellular concentrations of $\mathrm{K}^{+}$, pannexin 1 channels induce activation of caspase 1 (Silverman et al., 2009). Hypoxia causes increased extracellular concentrations of $\mathrm{K}^{+}$in brain slice cultures that can be inhibited by AR antagonism (Croning et al., 1995). Importantly, adenosine can stimulate cellular $\mathrm{K}^{+}$release through the A1 and A2A ARs (Fredholm et al., 2001, Sanjani et al., 2011).

Finally, the brain is rich in ARs, and they are expressed on a wide range of brain-based cells including microglia (A1, A2A, and A3) (Sperlágh and Illes, 2007), astrocytes (A1, A2A, A2B and A3), neurons (A1 and A2A) (Haskó et al., 2005), and endothelial cells (A2A and A3) (Fredholm et al., 2001; Platts and Duling, 2004). Thus, further work is needed to determine not only how adenosine activates caspase 1 but what are the particular brain cells most responsible for caspase 1 activation and the production of mature IL- $1 \beta$ after hypoxia/reoxygenation. Currently, some specificity to the brain is evident, because hypoxia/reoxygenation did not increase liver caspase 1 activity (data not shown). Taken together, our results indicate that hypoxia/reoxygenation increases caspase 1 activity in the brain, thereby impairing amygdala-based memory formation. These findings are important, because they delineate a new mechanism linking adenosine to activation of the inflammasome.

\section{References}

Avivi A, Brodsky L, Nevo E, Band MR (2006) Differential expression profiling of the blind subterranean mole rat Spalax ehrenbergi superspecies: bioprospecting for hypoxia tolerance. Physiol Genomics 27:54-64. CrossRef Medline

Bauernfeind FG, Horvath G, Stutz A, Alnemri ES, MacDonald K, Speert D, Fernandes-Alnemri T, Wu J, Monks BG, Fitzgerald KA, Hornung V, Latz E (2009) Cutting edge: NF-kappaB activating pattern recognition and cytokine receptors license NLRP3 inflammasome activation by regulating NLRP3 expression. J Immunol 183:787-791. CrossRef Medline

Beatty WW, Salmon DP, Bernstein N, Martone M, Lyon L, Butters N (1987) Procedural learning in a patient with amnesia due to hypoxia. Brain Cogn 6:386-402. CrossRef Medline

Berggren D, Gustafson Y, Eriksson B, Bucht G, Hansson LI, Reiz S, Winblad B (1987) Postoperative confusion after anesthesia in elderly patients with femoral neck fractures. Anesth Analg 66:497-504. Medline

Bickler PE, Hansen BM (1994) Causes of calcium accumulation in rat cortical brain slices during hypoxia and ischemia: role of ion channels and membrane damage. Brain Res 665:269-276. CrossRef Medline

Bi M, Naczki C, Koritzinsky M, Fels D, Blais J, Hu N, Harding H, Novoa I, Varia M, Raleigh J, Scheuner D, Kaufman RJ, Bell J, Ron D, Wouters BG, Koumenis C (2005) ER stress-regulated translation increases tolerance to extreme hypoxia and promotes tumor growth. EMBO J 24:3470-3481. CrossRef Medline

Broadbent NJ, Squire LR, Clark RE (2004) Spatial memory, recognition memory, and the hippocampus. Proc Natl Acad Sci U S A 101:1451514520. CrossRef Medline

Bruns RF (1991) Role of adenosine in energy supply/demand balance. Nucleosides Nucleotides 10:931-943. CrossRef

Calabresi P, Pisani A, Mercuri NB, Bernardi G (1995) On the mechanisms underlying hypoxia-induced membrane depolarization in striatal neurons. Brain 118:1027-1038. CrossRef Medline

Cao C, Loewenstein DA, Lin X, Zhang C, Wang L, Duara R, Wu Y, Giannini A, Bai G, Cai J, Greig M, Schofield E, Ashok R, Small B, Potter H, Arendash GW (2012) High blood caffeine levels in MCI linked to lack of progression to dementia. J Alzheimers Dis 30:559-572. Medline

Chen JF, Huang Z, Ma J, Zhu J, Moratalla R, Standaert D, Moskowitz MA, Fink JS, Schwarzschild MA (1999) A2A adenosine receptor deficiency attenuates brain injury induced by transient focal ischemia in mice. J Neurosci 19:9192-9200. Medline

Chen JF, Xu K, Petzer JP, Staal R, Xu YH, Beilstein M, Sonsalla PK, Castagnoli K, Castagnoli N Jr, Schwarzschild MA (2001) Neuroprotection by caffeine and a 2A adenosine receptor inactivation in a model of Parkinson's disease. J Neurosci 21:2-7. Medline

Cherubini A, Polidori MC, Bregnocchi M, Pezzuto S, Cecchetti R, Ingegni T, di Iorio A, Senin U, Mecocci P (2000) Antioxidant profile and early outcome in stroke patients. Stroke 31:2295-2300. CrossRef Medline

Costello DA, Watson MB, Cowley TR, Murphy N, Murphy Royal C, Garlanda C, Lynch MA (2011) Interleukin-1alpha and HMGB1 mediate hippocampal dysfunction in SIGIRR-deficient mice. J Neurosci 31:38713879. CrossRef Medline

Croning MD, Zetterström TS, Grahame-Smith DG, Newberry NR (1995) Action of adenosine receptor antagonists on hypoxia-induced effects in the rat hippocampus in vitro. Br J Pharmacol 116:2113-2119. CrossRef Medline

Cunha RA, Agostinho PM (2010) Chronic caffeine consumption prevents memory disturbance in different animal models of memory decline. J Alzheimer's Dis 20 [Suppl 1]:S95-S116.

Damiano JS, Oliveira V, Welsh K, Reed JC (2004) Heterotypic interactions among NACHT domains: implications for regulation of innate immune responses. Biochem J 381:213-219. CrossRef Medline 
Dantzer R, O'Connor JC, Freund GG, Johnson RW, Kelley KW (2008) From inflammation to sickness and depression: when the immune system subjugates the brain. Nat Rev Neurosci 9:46-56. CrossRef Medline

Davis-Devine S, Day SJ, Freund GG (2003) New red blood cell lysing fixative for use in fine needle aspiration and fluid cytology. Atca Cytol 47:630636. CrossRefMedline

Devasagayam T, Kamat J, Mohan H (1996) Caffeine as an antioxidant: inhibition of lipid peroxidation induced by reactive oxygen species. Biophys Acta 1282:63-70. CrossRef Medline

Di Virgilio F (2007) Liaisons dangereuses: P2X(7) and the inflammasome. Trends Pharmacol Sci 28:465-472. CrossRef Medline

Feuerstein GZ, Wang X, Barone FC (1997) Inflammatory gene expression in cerebral ischemia and trauma. Potential new therapeutic targets. Ann NY Acad Sci 825:179-193. CrossRef Medline

Fredholm BB, Bättig K, Holmén J, Nehlig A, Zvartau EE (1999) Actions of caffeine in the brain with special reference to factors that contribute to its widespread use. Pharmacol Rev 51:83-133. Medline

Fredholm BB, IJzerman AP, Jacobson KA, Klotz KN, Linden J (2001) International Union of Pharmacology. XXV. Nomenclature and classification of adenosine receptors. Pharmacol Rev 53:527-552. Medline

Galaris D, Eddy L, Arduini A, Cadenas E, Hochstein P (1989) Mechanisms of reoxygenation injury in myocardial infarction: implications of a myoglobin redox cycle. Biochem Biophys Res Commun 160:1162-1168. CrossRef Medline

Gascon G, Barlow C (1970) Juvenile migraine, presenting as an acute confusional state. Pediatrics 45:628-635. Medline

Godbout JP, Pesavento J, Hartman ME, Manson SR, Freund GG (2002) Methylglyoxal enhances cisplatin-induced cytotoxicity by activating protein kinase C $\delta$. J Biol Chem 277:2554-2561. CrossRef Medline

González-Correa JA, Muñoz-Marín J, Arrebola MM, Guerrero A, Narbona F, López-Villodres JA, De La Cruz JP (2007) Dietary virgin olive oil reduces oxidative stress and cellular damage in rat brain slices subjected to hypoxia-reoxygenation. Lipids 42:921-929. CrossRef Medline

González-Flecha B, Cutrin JC, Boveris A (1993) Time course and mechanism of oxidative stress and tissue damage in rat liver subjected to in vivo ischemia-reperfusion. J Clin Invest 91:456-464. CrossRef Medline

Goshen I, Kreisel T, Ounallah-Saad H, Renbaum P, Zalzstein Y, Ben-Hur T, Levy-Lahad E, Yirmiya R (2007) A dual role for interleukin-1 in hippocampal-dependent memory processes. Psychoneuroendocrinology 32:1106-1115. CrossRef Medline

Gozal D, Daniel JM, Dohanich GP (2001) Behavioral and anatomical correlates of chronic episodic hypoxia during sleep in the rat. J Neurosci 21:2442-2450. Medline

Guinzberg R, Cortés D, Díaz-Cruz A, Riveros-Rosas H, Villalobos-Molina R, Piña E (2006) Inosine released after hypoxia activates hepatic glucose liberation through A3 adenosine receptors. Am J Physiol Endocrinol Metab 290:E940-E951. CrossRef Medline

Hagberg H, Andersson P, Lacarewicz J, Jacobson I, Butcher S, Sandberg M (1987) Extracellular adenosine, inosine, hypoxanthine, and xanthine in relation to tissue nucleotides and purines in rat striatum during transient ischemia. J Neurochem 49:227-231. CrossRef Medline

Hart ML, Henn M, Köhler D, Kloor D, Mittelbronn M, Gorzolla IC, Stahl GL, Eltzschig HK (2008) Role of extracellular nucleotide phosphohydrolysis in intestinal ischemia-reperfusion injury. FASEB J 22:2784-2797. CrossRef Medline

Haskó G, Pacher P, Vizi ES, Illes P (2005) Adenosine receptor signaling in the brain immune system. Trends Pharmacol Sci 26:511-516. CrossRef Medline

Johnson DR, O'Connor JC, Hartman ME, Tapping RI, Freund GG (2007) Acute hypoxia activates the neuroimmune system, which diabetes exacerbates. J Neurosci 27:1161-1166. CrossRef Medline

Jones CE, Crowell JW, Smith EE (1968) Significance of increased blood uric acid following extensive hemorrhage. Am J Physiol 214:1374-1377. Medline

Keller M, Rüegg A, Werner S, Beer HD (2008) Active caspase-1 is a regulator of unconventional protein secretion. Cell 132:818-831. CrossRef Medline

Kobie JJ, Shah PR, Yang L, Rebhahn JA, Fowell DJ, Mosmann TR (2006) T regulatory and primed uncommitted CD4 T cells express CD73, which suppresses effector CD4 T cells by converting $5^{\prime}$-adenosine monophosphate to adenosine. J Immunol 177:6780-6786. Medline

Kostulas N, Pelidou SH, Kivisäkk P, Kostulas V, Link H (1999) Increased
IL-1, IL-8, and IL-17 mRNA expression in blood mononuclear cells observed in a prospective ischemic stroke study. Stroke 30:2174-2179. CrossRef Medline

Kyff JV, Vaughn S, Yang SC, Raheja R, Puri VK (1989) Continuous monitoring of mixed venous oxygen saturation in patients with acute myocardial infarction. Chest 95:607-611. CrossRef Medline

Lamkanfi M, Kanneganti TD, Franchi L, Núñez G (2007) Caspase-1 inflammasomes in infection and inflammation. J Leukocyte Biol 82:220-225. CrossRef Medline

Lavin DN, Joesting JJ, Chiu GS, Moon ML, Meng J, Dilger RN, Freund GG (2011) Fasting induces an anti-inflammatory effect on the neuroimmune system which a high-fat diet prevents. Obesity 19:1586-1594. CrossRef Medline

Layé S, Gheusi G, Cremona S, Combe C, Kelley K, Dantzer R, Parnet P (2000) Endogenous brain IL-1 mediates LPS-induced anorexia and hypothalamic cytokine expression. Am J Physiol Regul Integr Comp Physiol 279: R93-R98. Medline

Li C, Jackson RM (2002) Reactive species mechanisms of cellular hypoxiareoxygenation injury. Am J Physiol Cell Physiol 282:C227-C241. Medline

Lu H, Sun SQ (2003) A correlative study between AQP4 expression and the manifestation of DWI after the acute ischemic brain edema in rats. Chin Med J 116:1063-1069. Medline

Martinon F (2010) Signaling by ROS drives inflammasome activation. Eur J Immunol 40:616-619. CrossRef Medline

Ma XC, Gottschall PE, Chen LT, Wiranowska M, Phelps CP (2003) Role and mechanisms of interleukin-1 in the modulation of neurotoxicity. Neuroimmunomodulation 10:199-207. Medline

Miao EA, Rajan JV, Aderem A (2011) Caspase-1-induced pyroptotic cell death. Immunol Rev 243:206-214. CrossRef Medline

Mori E, Yamadori A (1987) Acute confusional state and acute agitated delirium. Occurrence after infarction in the right middle cerebral artery territory. Arch Neurol 44:1139-1143. CrossRef Medline

Moses SN, Cole C, Driscoll I, Ryan JD (2005) Differential contributions of hippocampus, amygdala and perirhinal cortex to recognition of novel objects, contextual stimuli and stimulus relationships. Brain Res Bull 67: 62-76. CrossRef Medline

Natale JE, Ahmed F, Cernak I, Stoica B, Faden AI (2003) Gene expression profile changes are commonly modulated across models and species after traumatic brain injury. J Neurotrauma 20:907-927. CrossRef Medline

Pétrilli V, Martinon F (2007) The inflammasome, autoinflammatory diseases, and gout. Joint Bone Spine 74:571-576. CrossRef Medline

Phillis JW (1995) The effects of selective A1 and A2a adenosine receptor antagonists on cerebral ischemic injury in the gerbil. Brain Res 705: 79-84. CrossRef Medline

Platts SH, Duling BR (2004) Adenosine A3 receptor activation modulates the capillary endothelial glycocalyx. Circ Res 94:77-82. CrossRef Medline

Poulsen JP, Oyasaeter S, Saugstad OD (1993) Hypoxanthine, xanthine, and uric acid in newborn pigs during hypoxemia followed by resuscitation with room air or 100\% oxygen. Crit Care Med 21:1058-1065. CrossRef Medline

Pugh CR, Fleshner M, Watkins LR, Maier SF, Rudy JW (2001) The immune system and memory consolidation: a role for the cytokine IL-1beta. Neurosci Biobehav Rev 25:29-41. CrossRef Medline

Raju PA, Herzenberg LA, Herzenberg LA, Roederer M (1994) Glutathione precursor and antioxidant activities of $\mathrm{N}$-acetylcysteine and oxothiazolidine carboxylate compared in in vitro studies of HIV replication. AIDS Res Hum Retroviruses 10:961-967. CrossRef Medline

Rees S, Mallard C, Breen S, Stringer M, Cock M, Harding R (1998) Fetal brain injury following prolonged hypoxemia and placental insufficiency: a review. Comp Biochem Physiol A Mol Integr Physiol 119:653-660. CrossRef Medline

Rodgers RJ, Johnson NJ, Carr J, Hodgson TP (1997) Resistance of experientially-induced changes in murine plus-maze behaviour to altered retest conditions. Behav Brain Res 86:71-77. CrossRef Medline

Rothwell N (2003) Interleukin-1 and neuronal injury: mechanisms, modification, and therapeutic potential. Brain Behav Immun 17:152-157. CrossRef Medline

Rudolphi KA, Schubert P (1997) Modulation of neuronal and glial cell function by adenosine and neuroprotection in vascular demential. Behav Brain Res 83:123-128. CrossRef Medline

Saikumar P, Dong Z, Weinberg JM, Venkatachalam MA (1998) Mecha- 
nisms of cell death in hypoxia/reoxygenation injury. Oncogene 17:33413349. Medline

Saito K, Suyama K, Nishida K, Sei Y, Basile AS (1996) Early increases in TNF- $\alpha$, IL- 6 and IL- $1 \beta$ levels following transient cerebral ischemia in gerbil brain. Neurosci Lett 206:149-152. CrossRef Medline

Sanjani MS, Teng B, Krahn T, Tilley S, Ledent C, Mustafa SJ (2011) Contributions of $\mathrm{A} 2 \mathrm{~A}$ and $\mathrm{A} 2 \mathrm{~B}$ adenosine receptors in coronary flow responses in relation to the KATP channel using $\mathrm{A} 2 \mathrm{~B}$ and $\mathrm{A} 2 \mathrm{~A} / 2 \mathrm{~B}$ double-knockout mice. Am J Physiol Heart Circ Physiol 301:H2322-H2333. CrossRef Medline

Sara SJ, Lefevre D (1972) Hypoxia-induced amnesia in one-trial learning and pharmacological protection by piracetam. Psychopharmacologia 25: 32-40. CrossRef Medline

Schroder K, Zhou R, Tschopp J (2010) The NLRP3 inflammasome: a sensor for metabolic danger? Science 327:296-300. CrossRef Medline

Sherry CL, O'Connor JC, Kramer JM, Freund GG (2007) Augmented lipopolysaccharide-induced TNF- $\alpha$ production by peritoneal macrophages in type 2 diabetic mice is dependent on elevated glucose and requires p38 MAPK. J Immunol 178:663-670. Medline

Sherry CL, Kramer JM, York JM, Freund GG (2009a) Behavioral recovery from acute hypoxia is reliant on leptin. Brain Behav Immun 23:169-175. CrossRef Medline

Sherry CL, Kim SS, Freund GG (2009b) Accelerated recovery from acute hypoxia in obese mice is due to obesity-associated up-regulation of interleukin-1 receptor antagonist. Endocrinology 150:2660-2667. CrossRef Medline

Shi X, Dalal NS, Jain AC (1991) Antioxidant behaviour of caffeine: efficient scavenging of hydroxyl radicals. Food Chem Toxicol 29:1-6. CrossRef Medline

Shukitt-Hale B, Stillman MJ, Lieberman HR (1996) Tyrosine administration prevents hypoxia-induced decrements in learning and memory. Physiol Behav 59:867-871. CrossRef Medline

Silverman WR, de Rivero Vaccari JP, Locovei S, Qiu F, Carlsson SK, Scemes E, Keane RW, Dahl G (2009) The pannexin 1 channel activates the inflammasome in neurons and astrocytes. J Biol Chem 284:18143-18151. CrossRef Medline

Sitkovsky M, Lukashev D (2005) Regulation of immune cells by local-tissue oxygen tension: HIFla and adenosine receptors. Nat Rev Immunol 5:712-721. CrossRef Medline

Sperlágh B, Illes P (2007) Purinergic modulation of microglial cell activation. Purinergic Signal 3:117-127. CrossRef Medline

Taguchi A, Wen Z, Myojin K, Yoshihara T, Nakagomi T, Nakayama D, Tanaka H, Soma T, Stern DM, Naritomi H, Matsuyama T (2007) Gran- ulocyte colony-stimulating factor has a negative effect on stroke outcome in a murine model. Eur J Neurosci 26:126-133. CrossRef Medline

Takao T, Culp SG, De Souza EB (1993) Reciprocal modulation of interleukin-1 beta (IL-1 beta) and IL-1 receptors by lipopolysaccharide (endotoxin) treatment in the mouse brain-endocrine-immune axis. Endocrinology 132:1497-1504. CrossRef Medline

Taniguchi H, Mohri I, Okabe-Arahori H, Aritake K, Wada K, Kanekiyo T, Narumiya S, Nakayama M, Ozono K, Urade Y, Taniike M (2007) Prostaglandin $\mathrm{D}_{2}$ protects neonatal mouse brain from hypoxic ischemic injury. J Neurosci 27:4303-4312. CrossRef Medline

Taupin V, Toulmond S, Serrano A, Benavides J, Zavala F (1993) Increase in IL-6, IL-1 and TNF levels in rat brain following traumatic lesion: influence of pre- and post-traumatic treatment with Ro5 4864, a peripheral-type (p site) benzodiazepine ligand. J Neuroimmunol 42: 177-185. CrossRef Medline

Touzani O, Boutin H, Chuquet J, Rothwell N (1999) Potential mechanisms of interleukin-1 involvement in cerebral ischaemia. J Neuroimmunol 100: 203-215. CrossRef Medline

Tschopp J, Schroder K (2010) NLRP3 inflammasome activation: the convergence of multiple signalling pathways on ROS production? Nat Rev Immunol 10:210-215. CrossRef Medline

Udayabanu M, Kumaran D, Nair RU, Srinivas P, Bhagat N, Aneja R, Katyal A (2008) Nitric oxide associated with iNOS expression inhibits acetylcholinesterase activity and induces memory impairment during acute hypobaric hypoxia. Brain Res 1230:138-149. CrossRef Medline

Wu B, Ma Q, Khatibi N, Chen W, Sozen T, Cheng O, Tang J (2010) AcYVAD-CMK decreases blood-brain barrier degradation by inhibiting caspase- 1 activation of interleukin- $1 \beta$ in intracerebral hemorrhage mouse model. Transl Stroke Res 1:57-64. CrossRef Medline

Xiong M, Yang Y, Chen GQ, Zhou WH (2009) Post-ischemic hypothermia for $24 \mathrm{~h}$ in $\mathrm{P} 7$ rats rescues hippocampal neuron: association with decreased astrocyte activation and inflammatory cytokine expression. Brain Res Bull 79:351-357. CrossRef Medline

Yirmiya R, Winocur G, Goshen I (2002) Brain interleukin-1 is involved in spatial memory and passive avoidance conditioning. Neurobiol Learn Mem 78:379-389. CrossRef Medline

York JM, Blevins NA, Meling DD, Peterlin MB, Gridley DS, Cengel KA, Freund GG (2012a) The biobehavioral and neuroimmune impact of low-dose ionizing radiation. Brain Behav Immun 26:218-227. CrossRef Medline

York JM, Blevins NA, Baynard T, Freund GG (2012b) Mouse testing methods in psychoneuroimmunology: an overview of how to measure sickness, depressive/anxietal, cognitive, and physical activity behaviors. Methods Mol Biol 934:243-276. 